\title{
Editorial
}

\section{The European Council and the national executives: SEGMENTATION, CONSOLIDATION AND LEGITIMATION}

Of the three branches of government traditionally distinguished since Montesquieu, two have received ample scholarly attention in their relation with the European Union. A plethora of books and articles have been written on the role and position of national courts and national parliaments in Europe. As to the former, the interaction of national courts with the Court of Justice of the European Union is still massively researched. As to the latter, it has been thoroughly analysed how national parliaments were sidelined from the start of the integration process, only to regain lost ground later. In particular, attempts to include the national parliaments in EU decision-making, via the renewed Subsidiarity Protocol among other ways, have attracted numerous research activities. ${ }^{1}$

By comparison, the least examined branch of government is the executive, or government in the strict sense, by which we mean the realm of presidents, cabinets, prime ministers and ministers. One of the reasons for this seems to be the presumption that the relation between the national executives and the Union seems rather straightforward: due to their strong involvement in decision-making at the European level they are traditionally seen as the 'winners' of European integration. But that is not the whole story, as the events from the past eighteen months testify.

Not long ago a professor of constitutional law - in a private chat on current developments in Europe - rhetorically asked: 'do you know of any member of a national executive who has lost their office because of Europe?' He had better not address that question now to Brian Cowen, Iveta Radičová, Silvio Berlusconi, George Papandreou, José Sócrates, José Zapatero, Nicolas Sarkozy or Mark Rutte. Indeed, the velocity with which heads of state or government of Eurozone countries have been turfed out is striking.

\footnotetext{
${ }^{1}$ See for instance the O.P.A.L. project (Observatory of Parliaments after the Lisbon Treaty), see $<$ www.opal-europe.org $>$.
}

European Constitutional Law Review, 8: 165-171, 2012

(C) 2012 T.M.C.ASSER PRESS and Contributors

doi:10.1017/S1574019612000132 
Certainly, in each case referred to above, the European dimension differs and so does the national context in each case. But as a matter of fact, we see that European and national politics and decision-making have become more intertwined than ever. This intertwinement particularly concerns the heads of state or government. In the near past, it was unthinkable that a head of government would be humiliated openly by other European Council members, would be put under pressure by them and by the European Central Bank to introduce austerity and reform measures domestically and would ultimately be forced to leave office for not living up to promises made. Yet all this happened to Silvio Berlusconi. This may be explained by two crucial notions to which Van Rompuy referred in his Humboldt lecture earlier this year: interdependence and co-responsibility ${ }^{2}$ (co-responsibility understood here as the responsibility of the national executives for 'the whole', both collectively at the European level and individually at the national level). We would like to add a third element: shared leadership. The ability to lead is an indispensable quality of the executive in general, and also in Europe, where this political leadership is shared by the national executives.

All this is not new. The triangle of interdependence, co-responsibility and shared leadership can be found in earlier European crises as well. We can refer to the informal European Council meeting in Paris on 18 November 1989, shortly after the fall of the Berlin Wall, the event marking the previous fundamental crisis in the process of European integration. It was felt among the participants then that 'for the first time, we were sitting around the table discussing a political issue like a cabinet at European level'. ${ }^{3}$ A few days later, Chancellor Kohl, in an historical appearance in the European Parliament, argued that 'we have a common interest and a joint responsibility in Europe for ensuring that the processes of reform (...) succeed'. ${ }^{4}$

There are three issues regarding our subject which may benefit from further research: (1) the segmentation of the national political executive; (2) the consolidation of the European Council's role and authority and the imperative of coherence and unity, and (3) the compartmented nature of the European Council's democratic legitimation. Central to these three issues is the conviction that the prism of $n a-$ tional constitutional law is no longer sufficient to fully capture and understand the functioning of national executives of the member states.

\footnotetext{
${ }^{2}$ Herman van Rompuy, 'The discovery of co-responsibility: Europe and the debt crisis', lecture at the Humboldt Universität, Walter Hallstein Institute for European Constitutional Law, Berlin 6 Feb. 2012.

${ }^{3}$ Belgian Prime Minister Wilfried Martens as quoted in the New York Times, Watershed in Europe, 22 Nov. 1989.

${ }^{4}$ Official Journal of the European Communities, Annex, Debates in the European Parliament, 1989-1990 Session, Report of proceedings from 20 to 24 Nov. 1989, No. 3-383, p. 159.
} 


\section{Segmentation and shifting responsibilities within national executives}

'National executives' are not monolithic entities, certainly not when we consider them in light of the European Union. The heads of state and government are at the top of the European political pyramid, where they collectively form the political executive of the Union. Due to the single-seat arrangement since the entry into force of the Lisbon Treaty, the ministers of foreign affairs who used to 'assist' the heads of state and government have been ousted formally and factually from the European Council. Finance ministers who were awarded a seat by the Maastricht Treaty for the discussion of matters relating to the Economic and Monetary Union are now only involved in ECOFIN and in the Eurogroup meetings. But even that position has come under threat by the formal establishment of 'Eurosummits' (Article 12 of the Fiscal Compact).

These developments inevitably affect relations and responsibilities within the national cabinets or governments. Even in states with a parliamentary system in which the prime minister is merely the primus inter pares, as is for instance the case in the Netherlands, regular cabinet ministers increasingly lose out vis-à-vis their heads of government. A recent letter from Herman van Rompuy to the members of the European Council can witness to this. He appealed to them 'to instruct your ministers responsible (...) to show the necessary sense of compromise to help the Presidency achieve results on what are key elements for growth in Europe. ${ }^{5}$ Another problem for regular cabinet ministers is that the division of tasks and responsibilities follows that of the European level rather than the other way around. This makes the heads of government the most prominent actors at the national level too, as the euro crisis once again demonstrates. All in all, the functioning of the European Council, and more generally that of the European executive, strains and alters ordinary cabinet relations. A question is how these developments are accommodated in national constitutional law.

The increased political weight of European Council membership is particularly felt in member states with a so-called semi-presidential system. In these systems, in which the president is not merely a figurehead but also a political mover, the question of who is to represent the state in the European Council can be particularly thorny: the president - as head of state - or the prime minister - as head of government. Romania may serve as a recent example.

Prime Minister Ponta's desire to represent Romania at the European Council meeting of 28 and 29 June 2012 - instead of President Băsescu - plunged the

\footnotetext{
${ }^{5}$ Letter from President of the European Council Herman van Rompuy to the members of the European Council, Brussels 26 April 2012.
} 
country into a full-blown constitutional crisis. ${ }^{6}$ Notwithstanding a judgment of the Constitutional Court that denied Ponta's claim, the prime minister nevertheless went to Brussels supported in that action by Parliament. This conflict mirrors the fight between Prime Minister Tusk and President Kaczyński of Poland in 2008. The prime minister denied the president the right to take the (second) Polish seat in European Council. In this case, too, the issue was referred to the constitutional court. In May 2009, the Polish Constitutional Tribunal ruled partially in favour of the president. ${ }^{7}$ This ruling is more or less in line with the solutions adopted in Finland (pre-Lisbon), ${ }^{8}$ and in France (during cohabitations), in which both prime minister and president attend European Council meetings.

However, the Polish Tribunal's attempt to uphold the delicate balance of power between prime minister and president was already outdated by the time of the ruling. It did not in any way anticipate the Lisbon Treaty's single-seat arrangement. The absence of the former solution may partly explain the intensity of the current Romanian conflict. Indeed, the single-seat arrangement seems to force the countries involved to make a hard choice between representation by either the president or the prime minister, a choice which may have repercussions on the balance of power internally.

\section{The consolidation of the European political executive and the imperative of coherence and unity}

Once elected, the heads of state or government qualitate qua take the driver's seat in European Union decision-making, carrying a responsibility they cannot escape from even if they would like to do so from time to time. As Herman van Rompuy put it: 'many of my colleagues would actually have been quite happy to take a less prominent role in solving this crisis! However, since the start of the Greek crisis the events forced such momentous decisions upon us that heads of government had to step in, together'?

This common responsibility has a bearing on the behaviour demanded from politicians in both arenas. One quality of the national executive that is indispensable is its ability and willingness to maintain coherence and unity among its

\footnotetext{
${ }^{6}$ On the place of the president in the Romanian system, see Elena Simina Tănăsescu, 'The President of Romania, Or: The Slippery Slope of a Political System', EuConst (2008) p. 64.

${ }^{7}$ Polish Constitutional Tribunal, decision of 20 May 2009, Ref. No. Kpt 2/08: 'The President of the Republic of Poland, as the supreme representative of the Republic, may - under Art. 126(1) of the Constitution - decide to participate in a particular session of the European Council, if he finds it useful for the exercise of the duties of the President of the Republic of Poland, specified in Art. 126(2) of the Constitution'.

${ }^{8}$ Antero Jyränki, 'Finland: Foreign Affairs as the Last Stronghold of the Presidency', EuConst (2007) p. 285 (304 et seq.).

${ }^{9}$ Supra n. 2.
} 
members, in word and in action, regarding policy decisions taken collectively. This need of coherence and unity is also vital in European government. We perceive a horizontal and a vertical dimension of these demands.

The horizontal dimension relates to the triangle of interdependence, co-responsibility and shared leadership introduced above. Heads of government or state can simply no longer afford to ignore the policy lines agreed upon in the European Council. Silvio Berlusconi had learned that lesson the hard way after he steadfastly refused to implement austerity measures agreed upon at the European level. The case of Berlusconi provides an interesting example of the way in which coherence, or unity, of such European policy is enforced by peer pressure in a much more stringent way than before.

The second dimension is of a vertical nature. Coherence and unity of European government also demand that members of the European Council take full responsibility in the national political arena for the European policy decisions that they agreed upon collectively, even if these do not reflect their personal or national preferences. This need for coherence and unity is not just a matter for the members of the European Council, but also for other members of the national executives. When - shortly after the June European Council meeting - the Finnish minister of finance openly questioned the decisions taken, it was as detrimental to Italian interest rates as it would have been if the Finnish prime minister had made such a statement.

However, forcing governments into line and to uphold decisions taken by the European Council can be rather difficult, not only politically, but also constitutionally. This is, among other things, due to the autonomy of European Council decision-making. This autonomy is a sine qua non for the Council's capacity to lead. ${ }^{10}$ But it grates with systems in which the most important government decisions have to be taken by the ministers collectively, in which (as a result) the ministers have to bear collective responsibility for cabinet decisions. Even if European Council meetings are meticulously prepared for in cabinet meetings, there's no control over the exact agenda of the European Council meetings. ${ }^{11}$ Often issues will have to be discussed and decided that are only tabled at the European Council meeting itself. The June meeting, in which it was decided that the ESM can directly support financial institutions, is but one example. This raises the question

\footnotetext{
${ }^{10}$ Even for members of the European Council itself, it is not always easy to acknowledge this autonomy, as can be observed with Dutch prime minister Mark Rutte. It appears that in the national arena, he merely attempts to explain that what was agreed in Brussels was not that much of a turn from what the agreed-upon preference ex ante had been.

${ }^{11}$ This is what the German federal government argued in the proceedings leading up to the latest judgement of the Bundesverfassungsgericht on the participatory rights of the Bundestag in EU affairs, see BVerfG, $2 B v E$ 4/11.
} 
of whether regular ministers, constitutionally, can be held responsible for (and are obliged to abide by) European Council decisions.

\section{The compartmented legitimacy of the European Council}

As said, the coherence and unity of European government also demand that members of the European Council take full responsibility in the national political arena for European policy decisions. For the heads of government, this arena is of course that of the national parliaments, to which they are accountable. Since the Euro crisis began, the scrutiny of national parliaments, which in Germany was urged by the constitutional court (see Antje von Ungern-Sternberg's contribution to this issue), ${ }^{12}$ has intensified, both prior to European Council meetings and afterwards. ${ }^{13}$ The crisis has emphasised that the European role of the national parliaments is far from being limited to scrutinizing the subsidiarity of Union legislative proposals (and approving from to time). The intensified scrutiny, which is not likely to abate, has several consequences.

First, the European Council has to anticipate to a certain extent the duty of its members to account for its decisions in their parliaments. In that respect, Van Rompuy aptly reflected these dynamics when he stated that in meetings of the European Council, one feels the presence of all these parliaments. (...) Many national leaders, in our discussions, refer to the position of their parliament, to defend specific amendments. ${ }^{314}$ By the way, standard majorities are not necessarily to be counted upon when approval is asked for European Council decisions. In Slovakia, a coalition party decided to withhold its support when Iveta Radičová tried to secure an expansion of the EFSF powers and resources.

If the heads of state or government are unable to muster the necessary support for the European Council's decisions, this may of course provoke a national government crisis, which, par ricochet, may turn into a European government crisis too. Yet another lesson to be learnt from the euro crises is that a government's demise need not result in a European government crisis. Despite the high casualty rate amongst its members, so far there is more continuity and stability in European Council government than the constant shifts in political power might suggest. This also works the other way around: the consistency of the European

\footnotetext{
${ }^{12}$ See the ruling of 19 June 2012 by the Bundesverfassungsgericht in favour of the Bundestag (arguing its position under Article $23 \mathrm{GG}$ was not respected by the federal government in the process of establishing the ESM, the fiscal compact and the 'Euro-Plus-Pact').

${ }^{13}$ See for an interesting overview of national systems of political accountability: Luc Verhey et al., Political Accountability in Europe, which way forward?, Europa Law Publishing, Groningen, 2008. On the European level, this book mainly focuses on the Commission-European Parliament axis. See in particular p. 8.

${ }^{14}$ Supra n. 2
} 
Council's policy affects the room for political change in several member states; a change of government does not necessarily bring about a change in Europe-induced policy, as the cases of Greece, Ireland, Portugal and Spain demonstrate.

In sum, the European Council's compartmented legitimacy need not diminish the coherence and unity of its policy, yet neither can one say that it functions in isolation from the national parliaments. In terms of democratic legitimacy, the relationship between the European Council and the national parliaments remains of great importance. What is evident is that the sedimentation of the developments in these relations is still in progress and needs to remain under close scholarly attention.

DN, JHR, TV 